\title{
Education, the wealth of nations, and political tolerance toward homosexuals: a multilevel analysis of 26 countries in the Americas
}

\author{
Mitchell Seligson ${ }^{1}$ \\ Daniel E. Moreno Morales² \\ Guilherme A. Russo ${ }^{3}$ (iD
}

\begin{abstract}
While the positive effect of education on political tolerance toward minorities is wellknown, we understand far less about education's impact on tolerance across varying contexts. Utilizing multilevel statistical techniques, we find an interactive effect indicating that education at the individual level has a greater effect on political tolerance toward those who identify as homosexuals in wealthier countries. The results suggest that (1) completing additional levels of schooling may be insufficient to promote tolerant attitudes toward this minority and (2) more investment in education leads to stronger impacts. We support this finding by showing that where educational expenditures are greater, the average impact of secondary education is larger. The study uses individual data from 26 countries in the 2014 AmericasBarometer as well as indicators from the World Bank DataBank and Freedom House.
\end{abstract}

Keywords: political tolerance; public opinion; Latin America; homosexuals

\section{Introduction $^{4}$}

Researchers from a wide variety of theoretical traditions have argued persuasively that a minimal level of tolerance of the political rights of others is a key ingredient in the democratic equation; intolerant political cultures form weak foundations for democratic institutions in part because they can place minorities at risk. In its most basic terms, democracy implies majority rule and minority rights (Dahl, 1971). Without tolerance for the rights of minorities, it is difficult to imagine how these groups' rights can be protected and how those minorities can accept the right to rule of the majority. Moreover, if intolerance by

1 Department of Political Science: Vanderbilt University. Nashville (TN), Estados Unidos. E-mail: $<$ mitchell.a.seligson@vanderbilt.edu>.

2 Ciudadanía, Comunidad de Estudios Sociales y Acción Pública. Cochabamba, Estado Plurinacional da Bolívia. E-mail: <daniel.moreno@ciudadaniabolivia.org>.

3 Center of Politics and Economics of the Public Sector (Cepesp) at the Getulio Vargas Foundation (FGV/SP). São Paulo (SP), Brasil. E-mail: <guilherme.russo@fgv.br>

4 Appendices A-M are available on the page of this article at Cesop's site: <https://www.cesop.unicamp.br/por/opiniao_publica>. 
majorities restricts minority opinion and even prevents it from being expressed, then minority groups have little chance of securing the right to run for office, let alone winning an election. The relevance of political tolerance has led researchers to look for the factors that are associated with it, at least since Stouffer's (1955) seminal work on U.S. citizens' willingness to tolerate Communists during the Cold War period. Yet, even after more than half a century of intensive research, we are left with more puzzles than answers (Gibson, $2006)^{5}$.

An ongoing search for factors that can help us better understand the elements that produce political tolerance remains an important but, thus far, elusive goal of political science research ${ }^{6}$. One basic agreement across nearly all studies in the tolerance research program is that the single most consistent finding is that more educated individuals (both among the mass publics and elite groups) are, on average, more tolerant than their peers with less education (Andersen and Fetner, 2008; Bobo and Licari, 1989; Dynes, 1967; Gibson, 2006; Jackman, 1972; Kirchner, Freitag, and Rapp, 2011; Nie, Junn, and Stehlik-Barry, 1996; Nunn, Crockett, and Williams, 1978; Prothro and Grigg, 1960; Stouffer, 1955). Educated individuals, it is argued, develop empathy with those different from themselves, and in so doing become willing to tolerate differences, largely without regard for the way in which tolerance is measured (Gibson, 1992). According to Lipset's (1959, p. 79) classic conception, education "broadens men's outlooks, enables them to understand the need for norms of tolerance, restrains them from adhering to extremist and monistic doctrines, and increases their capacity to make rational electoral choices." Whatever the causal mechanism, the consistency of the research means that we can accept as a given that education, ceteris paribus, is a reasonably strong predictor of political tolerance.

What is far less well established, and is therefore the central focus of this paper, is the impact of education on political tolerance across varying national and regional contexts. The great divide in tolerance research is between individual-level and aggregate-level explanations. While individual-level theories systematically point to education as one of the main predictors of political tolerance, aggregate theories point to characteristics of nations to explain variation in the overall levels of tolerance across countries. Aggregate-level explanations suggest that the level of development of nations largely shapes societies' political culture and ultimately contributes to the emergence and deepening of democracy (Lipset, 1959, 1961). If we consider national averages, abundant research shows that economically developed countries tend to score higher in many democratic values indicators, including tolerance (Inglehart, 1977, 1997, 2000; Inglehart and Norris, 2003; Inglehart and

\footnotetext{
${ }^{5}$ Our concerns of the practical importance of tolerance are grounded empirically as there is direct evidence that intolerant attitudes among the mass public affect the rights of minorities, and also translate into intolerant public policy (Gibson, 1988, 2008).

${ }^{6}$ It is not surprising, therefore, that political tolerance is one of the most studied subjects in political behavior (for reviews see Gibson, 2006; Mondak and Sanders, 2003).
} 
Welzel, 2005; Welzel and Inglehart, 2007)7. While the story behind the relationship between national wealth and tolerance is often not made explicit and is not necessarily consistent among theories, one prominent argument is that a widespread sense of economic security in more economically advanced countries leads to less competition for scarce resources and, in turn, to more harmonious and tolerant societies (Welzel and Inglehart, 2007).

To study this question, we focus on a single and contemporary aspect of tolerance, namely the public's views on the political rights of those who identify as homosexuals. Throughout Latin America and the Caribbean, the rights of homosexuals, particularly their right to marry, has been a burning minority-rights issue in the past few years. In some countries (Argentina, Brazil, Colombia, and Uruguay), homosexuals have been given the right to marry nation-wide; in Mexico, some jurisdictions have granted this right, while in Bermuda, partial recognition of rights was granted only to be rescinded in less than a year. In Costa Rica, gay marriage became the defining issue in the presidential election of 2018 immediately after the Inter-American Court of Human Rights ruled, only a month prior to the election, that same-sex marriage was a human right that, in the Court's view, the Costa Rican government had to grant. This issue has also played an important role in the most recent presidential election in Paraguay in 2018, with candidates publicly expressing their rejection of same-sex marriage in order to align with the majoritarian views of a conservative society. As tolerance toward the rights of homosexuals has become a salient topic throughout the region, in this paper, we examine the interactive effect of wealth at the macro-level and education at the individual-level on levels of tolerance toward the rights of homosexuals to run for office in the Americas. More precisely, we break new ground by arguing that the effect of education on tolerance toward the rights of gays varies according to a country's level of economic development, and we validate our argument across a large sample of economically diverse countries. We do this by analyzing cross-national data from 26 countries and subnational units within them.

\section{Micro and macro-level approaches to tolerance}

What constitutes the main strength of individual-level approaches to studying political tolerance paradoxically emerges as the major weakness of aggregate-level explanations, and vice-versa. In contrast to aggregate-level explanations, individual-level approaches tell us a great deal about the relationship between education and political tolerance in a single country but ignore the impact of contextual factors ${ }^{8}$. In doing so, they may underestimate the influence of national conditions on individuals' attitudes. On the other hand, cross-country studies at the aggregate level tend to treat each country as if there were

7 The tolerance measures used in the various Inglehart studies focus on tolerance toward homosexuals and lesbians, which is what we utilize here.

8 Aside from education, the literature on individual differences in views of homosexuality highlights the importance of religious affiliation, e.g.: Adamczyk and Pitt (2009), Heinze and Horn (2009), Hooghe et al. (2010). 
no important within-country variation in political tolerance at the individual level, in effect arguing that the average of a given dependent variable is "good enough" to represent all citizens (Inglehart, 1988, 1990). These national-level approaches often fail to demonstrate that a relationship between variables is also present within countries at the individual level. As a result, causal mechanisms often elude those findings (Seligson, 2002).

Considering both contextual and individual factors in political science research broadly, and in the study of political tolerance in particular, has become increasingly important (Franzese, 2007; Gibson, 2006; Steenbergen and Jones, 2002). For example, after reviewing the literature on political tolerance over 50 years after the publication of Stouffer's seminal work, Gibson concluded that "cross-national research on the role of context in shaping tolerance perceptions and judgments is especially necessary" (2006, p. 29). To date, however, only a very small number of studies have carried out cross-country statistical analysis of the determinants of political tolerance, and even fewer of those take into account how contextual factors shape individuals' political tolerance. The studies that do so include Peffley and Rohrschneider (2003), who find that the longevity of a country's democracy is positively associated with average levels of political tolerance, using survey data from 17 countries collected by the World Values Survey. The research by Weldon (2006) uses EuroBarometer data to argue that the process through which citizenship is acquired affects political and social tolerance levels in European countries ${ }^{9}$. As regards tolerance toward homosexuals specifically, Andersen and Fetner (2008), also using the World Values Survey for 35 countries, find that tolerance toward homosexuality seems to be negatively associated with a country's level of inequality. Adamczyk and Pitt (2009) find that older individuals, as well as those individuals to whom religion matters more, have increasingly disapproving views of homosexuality, with this last association being particularly strong in countries with more political and economic uncertainty (i.e.: nations characterized by a survival orientation as opposed to nations with more self-expression). Research on 20 European countries (Van Den Akker, Ploeg, and Scheepers, 2013) finds that levels of tolerance toward homosexuals are significantly higher in countries where same-sex marriage is legal. In Latin America, specifically, Dion and Díez (2017) find that, on average, respondents in richer and more democratic countries are more tolerant of same-sex marriage. Furthermore, their results indicate that those who are more educated and those who are less religious show higher levels of support, though this last association is moderated by age and urbanity.

While these studies help us understand which factors may increase or decrease overall levels of political tolerance, they do not explicitly focus on the interactive relationship between context-level variables and individuals' education ${ }^{10}$. Surprisingly, to our knowledge,

\footnotetext{
${ }^{9}$ A small number of studies also look at factors particular to country-dependent context. For example, a recent study (Peffley, Hutchison, and Shamir, 2015) examines the role of terrorist attacks in Israel on individual levels of tolerance.

${ }^{10}$ An exception is the work by Vatter, Stadelmann-Steffen, and Danaci (2014), that looks at how the effect of education on voting behavior vary by the type of referendum proposition in Switzerland.
} 
no study has yet tested cross-nationally the question of how contextual factors influence the well-documented relationship between education and political tolerance.

Another shortcoming of the literature is the inattention to differences within countries. Research has been carried out using multi-level models to examine the impact of the national context on an assortment of dependent variables (e.g., vote choice, ideological orientation, and political participation); other studies have looked at the subnational context ${ }^{11}$. However, as far as we know, no studies of political tolerance have looked at both the national and subnational contexts. Therefore, by examining the impact of national and subnational contextual characteristics, we break new ground in the literature about the link between education and tolerance. We ask: how does the effect of education on individuals' tolerance toward homosexuals vary across countries and across regions within countries? More broadly stated, we seek to understand if the effect of education on tolerance differs across contexts with varying levels of development.

\section{Varying effect of education}

The causal story linking education to tolerance is that individuals who achieve higher levels of education are exposed to wider views of the world, and learn to appreciate the fact that there are different religions, ethnicities, nationalities, and lifestyles. In short, they learn that their own perspectives may not be the only valid ones. Exposure to diversity creates empathy for "the other," and is thought to be a causal driver in the education-tolerance link (Rapp and Freitag, 2015). Lipset (1959) considered education as a "necessary" condition for achieving greater levels of tolerance and, in turn, more robust democracies.

The effect of national wealth is less well-understood than that of education at the individual level. Lipset's study, as well as the many studies that followed his pioneering effort on the link between economic development and democracy, focused on the presumed outcomes or correlates of tolerance, namely democratic regime type (Boix and Stokes, 2003; Cnudde and Neubauer, 1969; Przeworski et al., 2000). In more recent incarnations of this theory, the notion that national wealth is linked to specific sets of democratic culture values has been advanced by Inglehart and co-authors (Inglehart and Welzel, 2005; Welzel and Inglehart, 2007). For these authors, economic prosperity makes possible the emergence of democratic values such as tolerance.

We propose a different story. We theorize that, ceteris paribus, greater economic resources provide greater opportunities for the educational system to broaden individuals' outlooks, thus generating a stronger impact of education on tolerance in wealthier countries. Specifically, we claim that greater national economic resources make it possible to increase both the quantity and, of equal importance, the quality of education in a country,

\footnotetext{
${ }^{11}$ For example, Gibson (1988) examined the connections between characteristics of U.S. states (in this case, repressive legislation) and attitudinal intolerance.
} 
consequently increasing the rate of return of more education on tolerance. Randomized controlled research has shown that the levels of educational spending have a powerful effect on educational outcomes, both in terms of the short-term and long-term improvement in scores on standardized tests (Lafortune, Rothstein, and Schanzenbach, 2016), resulting in increased earnings and a lower incidence of poverty (Jackson, Johnson, and Persico, 2015; Jackson, Johnson, and Persico, 2016).

Cross-national research also shows that the quality of education, not just the level of education, varies significantly across countries, and that these differences can be traced back to the amount of resources made available for education. Greater national wealth means that countries have greater opportunities for investing in education and improving school quality (Puryear and Ortega, 2011). In fact, in a landmark study comparing education and development in Asia to Latin America, it was found that investment per child in the former, which grew dramatically from the 1950s through the 1980s, was the single greatest factor in explaining the Asian growth miracles (Birdsall, Ross, and Sabot, 1995; McGuire, 1994). In contrast, economic growth was far slower in Latin America, where the investment per child generally did not see any increases whatsoever (Birdsall, Ross, and Sabot, 1995; McGuire, 1994). Besides the political will to enact pro-education policies, the amount of money spent on education quality is largely contingent on a nation's wealth. These budgets heavily influence the basic resources of the school system, including the quality of teachers and, in general, the overall quality of the educational process. Since investment in education is constrained or facilitated by levels of national wealth and conditioned by public policy decisions and regime type (Huber, Mustillo, and Stephens, 2008), we expect not only to find higher overall levels of tolerance in affluent countries, but also higher rates of return to schooling on political tolerance. Consequently, years of education alone should not produce the same results as it does in countries that spend more money on $\mathrm{it}^{12}$. For example, a recent study with university students in Peru found that extra semesters of education are not associated with more tolerance (Stojnic and Alfaro, 2016); similarly, previous research showed that a decade ago education failed to increase tolerance among the Bolivian public (Moreno and Seligson, 2006). These results contradict the well-established pattern found in the United States and Western Europe ${ }^{13}$.

\footnotetext{
12 The research on tolerance suggests that the mechanism by which education affects tolerance is the development of empathy via exposure to ways of thinking different from one's own. Unfortunately, it is difficult to test the validity of this "broaden outlooks and develop empathy" hypothesis since many forms of instruction go on inside (and outside) of a classroom during a student's school years. But the biggest obstacle to directly testing the relationship between education and tolerance in a multilevel setting has to do with the quality and comparability of data on the quality of education and the resources devoted to increasing it. Educational statistics are often not comparable across school districts, let alone nationally or cross-nationally (Ortmanns and Schneider, 2016). We attempt to overcome this limitation by seeking patterns in the relationship between levels of education and political tolerance with comparable cross-national survey data and supplementary contextual-level factors.

${ }^{13}$ Another potential mechanism for why more educated individuals tend to present higher levels of tolerance, especially in the more economically developed nations, is social desirability. In other words, if those with higher
} 
Nonetheless, we can sharpen the causal mechanism by which it does so. One thing that richer countries can do is invest more in education, but not all do (as we note in our analysis below). We therefore deepen our analysis by exploring directly the impact of the amount of resources dedicated to education. If a poor country invests a larger proportion of its resources in education, it may also produce a greater marginal return on tolerance associated with the effect of more years of education. Therefore, we expect that the marginal effect of completing an additional level of education (e.g., primary vs. secondary) in a developed country with a context abundant in proper conditions for education is not likely to be the equivalent of doing so in a country with far lower resources available to be spent on the educational system. Thus, we hypothesize that the way in which education affects political tolerance is conditional on national wealth and expenditure on education.

\section{Measuring political tolerance}

To test this hypothesis, we use individual-level data from the 2014 AmericasBarometer surveys carried out by the Latin American Public Opinion Project (Lapop). The surveys are nationally representative of the non-institutionalized, voting-aged adult populations in each country, and covered a total of 28 countries of the Americas in 2014 . We do not include the United States and Canada in our analysis owing to the unavailability of key survey questions in these countries. That still leaves us with coverage of virtually all Latin America and much of the Caribbean. We can leverage the stratified nature of each country sample to allow us to go where few comparative political studies have gone before, carrying out our multi-level analysis on more than two levels: we look at nations, regions within nations, and, of course, individuals themselves. Specifically, because we know that there are important political and economic differences across regions within many of these 26 nations, we extend our exploration of the variation in the effect of education on tolerance for regions within these same countries ${ }^{14}$. In other words, given that the surveys are each representative of regions (defined operationally as sample strata) of a country, we have added region as an additional layer between individuals and countries to our analysis. In

\footnotetext{
levels of education believe that verbalizing intolerant attitudes contradicts social norms more than their less educated counterparts, then the positive correlation between education and tolerance could be a product of social desirability, a survey measurement artifact, rather than true differences in attitudes. On one hand, evidence from cross-national surveys that the more educated tend to give more homogenous answers (Inglehart, 1977) partially supports this idea. Yet (Wagner and Zick, 1995) testing of this hypothesis with less social-desirable measures and original experimental data contradicts this idea.

14 Previous works have indicated important variation across regions of the same country (Giraudy, 2012), including uneven process of democratization (Behrend, 2011; Gibson, 2010), varying levels of state capacity (Hiskey, 2005), and varying territorial interests (Falleti, 2010). Our decision to explore subnational variation here is driven by this growing literature on differences across subnational units, although we do not have clear expectations for why the impact of education on tolerance should vary across regions.
} 
total, our analysis includes data from 50,450 respondents within 140 regions in 26 countries ${ }^{15}$.

Comparability of tolerance measures has been a difficult task for scholars given that the salience of disliked groups varies across countries and over time. For example, Stouffer's (1955) classic study in the U.S. on tolerance toward the political rights of communists would not have had the same salience in a number of other countries, nor would it in the post-Cold War U.S. The shift of attitudes toward communism was one major reason that tolerance was shown as increasing in the U.S. when, in fact, the increase was largely a product of the decreasing threat of communism (Sullivan, Pierson, and Marcus, 1979). Similarly, recent multi-level, cross-national studies of European tolerance toward immigrants have, of necessity, used distinct migrant groups in each country and then adjusted the immigrant targets to fit the migration patterns in each country (Braun, Behr, and Kaczmirek, 2013; Peffley and Rohrschneider, 2003). Moreover, cross-national comparisons using the "leastliked" group approach (Sullivan, Pierson, and Marcus, 1979, 1982) that has tended to dominate the field for a number of years entails a few assumptions. Data from Lapop surveys conducted in Latin America have led to the discovery that in some countries, half or more of respondents refused to pick a group from the list handed to them, telling interviewers that they liked everyone-this consequently produced extreme heteroskedasticity on the dependent variable because large portions of some national samples would have missing data. Further, the list of groups from which individuals select within each country would have to be different in order to be locally salient. In one country, the list might include organizations of ethnic or religious groups, while in others it might include terrorist groups ${ }^{16}$.

We operationalize political tolerance toward homosexuals, the dependent variable, with a measure that asks respondents the extent to which people who identify as homosexuals should have the right to run for public office: D5. "Thinking of homosexuals, how strongly do you approve or disapprove of such people being permitted to run for public office?" Responses were measured using a 10-point "strongly disapprove"-"strongly approve" scale ${ }^{17}$. This approach to measuring tolerance toward individuals who identify as

\footnotetext{
${ }^{15} \mathrm{~A}$ Table $\mathrm{C} 1$ with the number of respondents per region and country appears in Appendix C. The stratification by country is based on individualized national understandings of regional divisions. For example, in Ecuador, most people normally think of the country as being divided into three distinct cultural/geographic regions (the coast, the Andean highlands, and the Amazonian region). The number of regions per country does not exceed nine and is usually on the order of five. Moreover, we correct the national estimates by recognizing differences in size between regions within countries by assigning weight based on the region's population size relative to the country's population. For instance the Argentine region of Patagonia receives a lot less weight in the calculation of the national-level effect than the metropolitan region of Buenos Aires.

${ }^{16}$ For example (Caspi and Seligson, 1983; Seligson and Caspi, 1984) looked at tolerance toward the Palestinian Liberation Organization (PLO) in Israel, an organization that at that time had been associated with numerous terrorist attacks, hijackings and kidnappings.

17 Average responses to this item across countries are presented in Appendix E and J. Uruguay presents the highest average response at 8.04, while Haiti presents the lowest score at 1.94. In line with previous works cited above, levels of political tolerance toward homosexuals are, on average, higher in countries such as Argentina, Chile, and Costa Rica than poorer countries in the sample such as Ecuador, Peru, Paraguay, and Bolivia.
} 
homosexuals has a number of virtues. First, by asking individuals directly about a basic, less ambiguous political right (i.e., the right to run for office), the survey item reduces imprecision compared to questions that might ask about abstract concepts such as "freedom of speech," which may mean different things to different respondents. Second, selecting individuals who identify as homosexuals as the minority group about which individuals are asked offers the advantage of its presence in every country in our sample. And third, we can satisfy the "objection precondition" by only analyzing the political tolerance toward homosexuals among individuals who have at least some objection to this minority, measured by responses of some disapproval to the rights of gays to marry (Gibson, 2013). In other words, by excluding from the analysis respondents who expressed, in a separate item, complete approval of same-sex marriage (i.e. responded "10", meaning they completely agree), we restrict the sample to individuals who have at least some objection to individuals who identify as homosexual. In reality, however, this omission of $14.5 \%$ of the sample does not produce any differences in the direction or significance of the results ${ }^{18}$.

\section{Modeling and results}

We begin our analysis by first assessing whether in our sample more education at the individual level is associated with a higher level of political tolerance toward homosexuals. To do so, we look at the differences in tolerance across individuals' levels of education ${ }^{19}$ while controlling for a number of socio-demographic factors by running multivariate ordinary least squares (OLS) regression per stratum of each country (i.e., 140 separate regressions). That is, we use the fact that samples were drawn as representative of each sub-national region to estimate the change in tolerance associated with having completed secondary school (compared to those who only finished primary school), and the effect of higher education (completing post-secondary training vs. holding only a secondary degree) per stratum. Besides standard socio-demographic controls such as sex, age, urban/rural, and wealth, we also control for ethnicity, religious affiliation, religiosity, frequency of internet use, level of attention to the news, and the education of the respondent's mother, to avoid possible bias from a confounding mechanism originating within the family upbringing of the individual. The wording of the survey items and coding of individual-level variables is presented in the Appendix $A$, and the code for the analysis is presented in the Appendix M.

For the sake of space, we do not show the results from the 140 stratum-level regressions. Instead, we show the distribution of the education coefficients graphically. Figure 1 presents the variation in estimated change in tolerance toward homosexuals having

\footnotetext{
18 We present the results of the regression models without the exclusion of cases in Appendix $L$.

19 The question asked the number of completed years of education, but in the analysis this information is recoded into four categories, no education, primary, secondary and higher education. This was done taking into account national differences across countries on how many years of education comprise each category. For example, in some countries, middle school starts at $6^{\text {th }}$ grade, while in others it starts at $7^{\text {th }}$. The detailed coding is presented in Appendix A.
} 
the right to run for public office associated with completing another education level. The figure on the left shows the coefficients associated with having completed secondary school as opposed to having completed primary school after controlling for the demographic and socio-economic factors. Similarly, the figure on the right presents the average difference in tolerance between two analogous individuals who hold a post-secondary degree, and their peers who hold no more than a secondary degree. Each circle represents the coefficient of completing an extra level of education based on the region's individual-level regression. Circles to the right of the line indicate a positive effect.

\section{Figure 1}

\section{Change in tolerance associated with completing an} extra level of formal education ${ }^{20}$

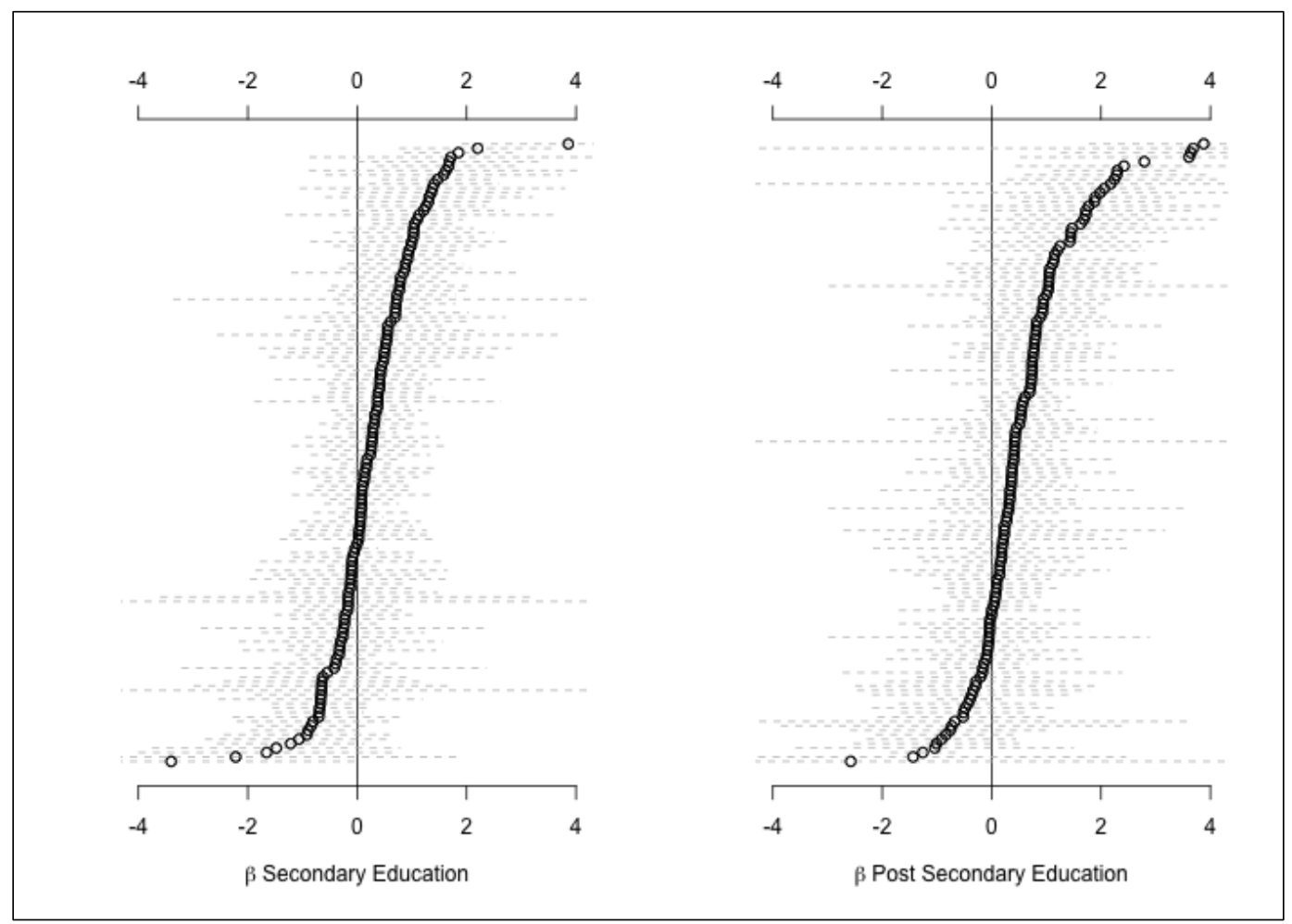

Source: Created by the authors using data from the AmericasBarometer 2014.

Our results, not surprisingly, confirm prior research, namely that individuals with more education, especially at the level of post-secondary school, are found to be, on average, and holding other factors constant, more tolerant. While there are some cases on the negative side and large confidence intervals, likely due to small samples and random sampling variability, the overall distribution of coefficients provides a validation for the

${ }^{20} \mathrm{~A}$ similar graph without the confidence intervals is presented in Appendix F. 
standard hypothesis that tolerance is positively associated with rising levels of education. We know from this first analysis then, that there is nothing unusual about the data or the question that measures tolerance given that the results conform closely to expectations. Furthermore, the question measuring tolerance for the political rights of gays is identical across 26 nations and 140 strata, thus giving us confidence that our comparative study is on the right track. But, as stated in our introduction, the purpose of this paper is to go beyond that initial individual-level finding and look at the relationship between education and tolerance in context. Our core interest is explaining the variation in the difference of tolerance promoted by education at the national and subnational levels that we may be able to attribute to national wealth. Formally stated, we hypothesize that in richer countries or in those that spend more on education, schools are likely to have more resources with which to provide students with the resources and experiences that lead to a broadly higher quality education in many respects. This, in turn, leads to a stronger effect of education on tolerance.

To compare the effect of education across both subnational regions and countries, we need to combine the data from the region-level separate regressions ${ }^{21}$. We use a twostep approach to analyzing nested data, which differs in a few key ways from multilevel (or hierarchical) linear modeling (HLM), for two reasons ${ }^{22}$. First, we have a far larger number of observations at the first level clustered within countries than researchers typically do in the field of education, from where the HLM approach emerged. This applies even when we look at regions, and certainly when we look at entire countries where the data are composed of typically 1,500 respondents $^{23}$. The classic use of HLM is based on the classroom, where the $\mathrm{N}$ rarely exceeds $50-60$ students, and often is as small as 15-20. Our strata-level samples, in contrast, are often in the hundreds. Having a larger number of observations per cluster (region) allows us to leverage the variation in our sample to more adequately estimate our parameters (Franzese, 2005; Gelman, 2005; Jusko and Shively, 2005). Second, our decision to use the multilevel two-step approach is also based on the fact that we are analyzing variation in the effect of education across strata, and not simply the average levels of the dependent variable per cluster ${ }^{24}$. This difference is important because in a random effects hierarchical model, if coefficients from other independent variables co-vary with the effect of interest (e.g., difference in tolerance between gender co-varies with difference in tolerance between groups of education) but the model does not account for this co-variation, the

\footnotetext{
21 It should be noted that the use of the word "effect" here does not imply a test in which the variation is exogenous as one might expect in a researcher-controlled experiment, but rather the change in tolerance associated with an increase of one completed level of education, holding the other predictors in the variable constant.

22 For an example of how this approach is used, see (Duch and Stevenson, 2005), and for an extended discussion on the advantages and disadvantages of using the two-step hierarchical estimation, see the special issue in Political Analysis 13(4) from 2005 (in particular, Franzese, 2005; Gelman, 2005; Jusko and Shively, 2005).

${ }^{23}$ We also ran a traditional hierarchical model of tolerance with random effects for years of education, which corroborates our hypotheses, and is presented in Appendix I.

24 In Appendix $\mathrm{H}$, we present a more detailed discussion regarding the assumption made by the standard hierarchical regression analysis with cross-level interactions.
} 
estimates for the random effect of interest can be biased (Franzese, 2005; Gelman, 2005; Jusko and Shively, 2005). Thus, because we currently do not have the computational power to model all coefficients as varying randomly simultaneously (i.e., variation and co-variation of random effects, which implies an increasingly large number of parameters to be estimated), we choose to run each of the regressions separately without relying on an assumption with which we are not comfortable (Duch and Stevenson, 2005; Gelman, 2005; Jusko and Shively, 2005). Nevertheless, our option for this approach produces disadvantages such as stratum-level regressions with a small number of observations (and consequently large standard errors) and potentially smaller statistical power in the second-level analysis.

Therefore, after estimating the effects of education levels per stratum separately, we combine these coefficients to turn them into our new dependent variables (i.e., the effects of completing secondary and post-secondary education on tolerance) ${ }^{25}$. In exploring the variation across regions, we produce measures of urbanization, Internet use, and wealth per region by aggregating individual-level information from the representative samples of each region and introduce them in our model. But given that the each sub-national region (sample stratum) is an independent second-level observation, we need to account for the fact that they belong to the same country and are of different sizes, so we recognize them as being part of a same cluster (country) that shares national-level characteristics and correct for differences in size between regions by assigning them weights proportional to their relative size, as well as adding the number of observations per regression as a control for the differences in the estimation of the effects of education. This multi-level method enables us to assess the impact of a country's wealth on the effect of education while still allowing for variation across subnational regions.

Our main contention is that the wealth of a country should increase the change in tolerance associated with more education. To assess this national-level prediction, we run standard multilevel regressions in which the coefficients from the individual-level regressions of regions are clustered within countries, and operationalize national wealth as the log of the 2012 Gross National Income per capita (in PPP dollars) with data from the World Bank databank ${ }^{26}$. As we have argued, wealthier countries, ceteris paribus, are likely to have more resources to invest in an education that provides students with distinct experiences and exposure to different ways of thinking, making its impact greater ${ }^{27}$. Given that we do not

\footnotetext{
25 We also estimated the differences between those with no education and primary education; however, the number of respondents with no education is small, less than $10 \%$ in all countries, which hinders the reliability of estimates.

${ }^{26} \mathrm{~A}$ measure of the country's wealth in purchasing power parity terms divided among the population in current US dollars. We use data from 2012 because it was the most recent year for which we have complete data prior to the survey.

27 Investment is not always converted into quality of education because of many factors, including poor policy design, failure in implementation, corruption and inefficiency. Nevertheless, we do not have reasons to believe there would be systematic variation in our sample of Latin American and Caribbean countries, at least to the point of affecting our estimates.
} 
explicitly show this causal link, as a robustness check and attempt to corroborate this assumption, appendix $\mathrm{K}$ provides a correlational test linking our key independent variables, national wealth and share of expenditure, and measures of education quality across countries.

We also deepen our analysis by exploring directly the impact of a measure of the amount of resources dedicated to education. To test this relationship, we include in the model the percent of GDP spent on education per country using World Bank data. The World Bank has data for only 23 of the 26 countries in our dataset, and we were unable to find data to fill in these gaps ${ }^{28}$. For this reason, we present separately models with and without this variable. Additionally, we need to control for confounding factors that are correlated with national wealth. Given what we know from the prior research on the factors beyond education that might play a role in national levels of tolerance, we include four controls: 1) the national level of democracy, as measured by the (inverted) Freedom House Index score; 2 ) the stock of democracy, measured as the number of years a country has been a democracy since 1946 with data from Cheibub, Gandhi, and Vreeland (2010); 3) the Gini Index of national-level income inequality from the World Bank Databank; and 4) a dichotomous measure of whether same-sex marriage was legal throughout the country in 2013. We present a Table B1 with descriptive statistics of these predictors in Appendix B. Because of (a small number of) missing data points, we include The Stock of Democracy and Gini Index in a third regression model to show the step-wise reduction in the number of observations ${ }^{29}$.

\footnotetext{
${ }^{28}$ We do not have data for Bahamas, Haiti and Suriname. The Bahamas has a population of fewer than 400,000 people, and the latter two are among the poorest in the region.

29 We present the partition of the variance with the "null" model, and how it would compare to a model with only micro-level predictors in the Appendix G.
} 
Table 1A

Hierarchical linear models of the effect of education on tolerance across strata

\begin{tabular}{|c|c|c|c|c|c|c|c|}
\hline & Variable & $\beta$ & (S.E.) & $\beta$ & (S.E.) & $\beta$ & (S.E.) \\
\hline \multirow{3}{*}{$\begin{array}{l}\text { Region- } \\
\text { Level } \\
\text { (First) }\end{array}$} & Internet use & $-0.66 * *$ & $(0.27)$ & $-0.54 *$ & $(0.29)$ & -0.47 & $(0.36)$ \\
\hline & $\%$ Urbanization & -0.03 & $(0.26)$ & -0.08 & $(0.25)$ & $-0.54 * *$ & $(0.24)$ \\
\hline & $\begin{array}{l}\text { \% Lowest } \\
\text { income quintile }\end{array}$ & -0.29 & $(0.77)$ & 0.30 & $(1.02)$ & 0.01 & $(1.14)$ \\
\hline \multirow[b]{2}{*}{$\begin{array}{l}\text { Regression- } \\
\text { Level (First) }\end{array}$} & $\begin{array}{l}\text { Log of \# of } \\
\text { observations }\end{array}$ & $1.86 *$ & $(1.08)$ & $2.15^{*}$ & $(1.10)$ & 1.00 & $(2.04)$ \\
\hline & $\begin{array}{l}\text { Log \# of } \\
\text { observations- } \\
\text { squared }\end{array}$ & -0.13 & $(0.09)$ & $-0.17^{*}$ & $(0.09)$ & -0.05 & $(0.19)$ \\
\hline \multirow{7}{*}{$\begin{array}{l}\text { Country- } \\
\text { Level } \\
\text { (Second) }\end{array}$} & $\begin{array}{l}\text { Log of GNI/pc } \\
2012\end{array}$ & $1.10 * * *$ & $(0.31)$ & $1.11^{* * *}$ & $(0.41)$ & $0.85 * *$ & $(0.41)$ \\
\hline & $\begin{array}{l}\text { Expenditure on } \\
\text { education } \%\end{array}$ & . & . & 0.08 & $(0.05)$ & $0.23 * * *$ & $(0.08)$ \\
\hline & $\begin{array}{l}\text { Level of } \\
\text { democracy } \\
\text { (freedom } \\
\text { house) }\end{array}$ & 0.03 & $(0.04)$ & 0.01 & $(0.04)$ & 0.03 & $(0.05)$ \\
\hline & $\begin{array}{l}\text { Log of } \\
\text { population } \\
\text { density }\end{array}$ & -0.01 & $(0.09)$ & 0.05 & $(0.12)$ & 0.18 & $(0.17)$ \\
\hline & $\begin{array}{l}\text { Same-sex } \\
\text { marriage }\end{array}$ & -0.07 & $(0.26)$ & -0.16 & $(0.27)$ & -0.24 & $(0.31)$ \\
\hline & $\begin{array}{l}\text { Stock of } \\
\text { democracy }\end{array}$ & . & . & . & . & 0.01 & $(0.01)$ \\
\hline & Gini index & . & . & . & . & -0.01 & $(0.03)$ \\
\hline & Constant & $-8.28 * *$ & $(3.80)$ & $-9.73 * * *$ & $(3.80)$ & -6.25 & $(5.26)$ \\
\hline & $\begin{array}{l}\text { Number of } \\
\text { observations }\end{array}$ & \multicolumn{2}{|c|}{140} & \multicolumn{2}{|c|}{127} & \multicolumn{2}{|c|}{105} \\
\hline & $\begin{array}{l}\text { Number of } \\
\text { countries }\end{array}$ & \multicolumn{2}{|c|}{26} & \multicolumn{2}{|c|}{23} & \multicolumn{2}{|c|}{18} \\
\hline & $\begin{array}{l}\text { Variance } \\
\text { (country) }\end{array}$ & 0.32 & $(0.04)$ & 0.30 & $(0.04)$ & 0.29 & $(0.05)$ \\
\hline & Residual & 0.53 & $(0.05)$ & 0.54 & $(0.06)$ & 0.59 & $(0.07)$ \\
\hline
\end{tabular}

Source: Created by the authors using data from the AmericasBarometer 2014 surveys, World Bank Databank, Freedom House, Cheibub, Gandhi, and Vreeland (2010), and the AmericasQuarterly report on Gay Marriage in the Social Inclusion Index.

Note: $* * p<0.05, * p<0.10$; Coefficients are hierarchical linear regression estimates with robust standard errors. 
Table 1B

Hierarchical linear models of the effect of education on tolerance across strata

\begin{tabular}{|c|c|c|c|c|c|c|c|}
\hline & & \multicolumn{6}{|c|}{ Effect of higher education } \\
\hline & Variable & $\beta$ & (S.E.) & $\beta$ & (S.E.) & $\beta$ & (S.E.) \\
\hline \multirow{3}{*}{$\begin{array}{l}\text { Region-Level } \\
\text { (First) }\end{array}$} & Internet use & -0.19 & $(0.29)$ & -0.29 & $(0.34)$ & -0.28 & $(0.28)$ \\
\hline & $\%$ Urbanization & 0.12 & $(0.28)$ & $0.43 * *$ & $(0.52)$ & 0.33 & $(0.29)$ \\
\hline & $\begin{array}{l}\text { \% Lowest income } \\
\text { quintile }\end{array}$ & -0.39 & $(1.11)$ & -0.96 & $(1.31)$ & -0.43 & $(1.28)$ \\
\hline \multirow[b]{2}{*}{$\begin{array}{l}\text { Regression- } \\
\text { Level (First) }\end{array}$} & $\begin{array}{l}\text { Log of \# of } \\
\text { observations }\end{array}$ & 0.80 & $(1.04)$ & -1.06 & $(1.03)$ & -0.63 & $(1.72)$ \\
\hline & $\begin{array}{l}\text { Log \# of } \\
\text { observations- } \\
\text { squared }\end{array}$ & -0.05 & $(0.09)$ & 0.07 & $(0.09)$ & 0.04 & $(0.16)$ \\
\hline \multirow{7}{*}{$\begin{array}{l}\text { Country-Level } \\
\text { (Second) }\end{array}$} & $\begin{array}{l}\text { Log of GNI/pc } \\
2012\end{array}$ & 0.57 & $(0.51)$ & 0.24 & $(0.55)$ & 0.61 & $(0.38)$ \\
\hline & $\begin{array}{l}\text { Expenditure on } \\
\text { education } \%\end{array}$ & . & . & 0.01 & $(0.04)$ & -0.09 & $(0.06)$ \\
\hline & $\begin{array}{l}\text { Level of } \\
\text { democracy } \\
\text { (freedom house) }\end{array}$ & -0.04 & $(0.05)$ & -0.04 & $(0.04)$ & 0.02 & $(0.03)$ \\
\hline & $\begin{array}{l}\text { Log of population } \\
\text { density }\end{array}$ & 0.13 & $(0.17)$ & $0.36 * * *$ & $(0.11)$ & 0.22 & $(0.15)$ \\
\hline & $\begin{array}{l}\text { Same-sex } \\
\text { marriage }\end{array}$ & -0.17 & $(0.28)$ & 0.09 & $(0.20)$ & $0.35^{* *}$ & $(0.17)$ \\
\hline & $\begin{array}{l}\text { Stock of } \\
\text { democracy }\end{array}$ & . & . & . & . & $-0.02 * *$ & $(0.01)$ \\
\hline & Gini index & . & . & . & . & 0.00 & $(0.01)$ \\
\hline & Constant & 1.88 & $(3.72)$ & 3.39 & (3.91) & 1.71 & (5.25) \\
\hline & $\begin{array}{l}\text { Number of } \\
\text { observations }\end{array}$ & \multicolumn{2}{|c|}{140} & \multicolumn{2}{|c|}{127} & \multicolumn{2}{|c|}{105} \\
\hline & $\begin{array}{l}\text { Number of } \\
\text { countries }\end{array}$ & \multicolumn{2}{|c|}{26} & \multicolumn{2}{|c|}{23} & \multicolumn{2}{|c|}{18} \\
\hline & $\begin{array}{l}\text { Variance } \\
\text { (country) }\end{array}$ & 0.38 & $(0.08)$ & 0.28 & $(0.06)$ & 0.16 & $(0.04)$ \\
\hline & Residual & 0.61 & $(0.06)$ & 0.62 & $(0.07)$ & 0.62 & $(0.08)$ \\
\hline
\end{tabular}

Source: Created by the authors using data from the AmericasBarometer 2014 surveys, World Bank Databank, Freedom House, Cheibub, Gandhi, and Vreeland (2010), and the AmericasQuarterly report on Gay Marriage in the Social Inclusion Index.

Note: $* * p<0.05, * p<0.10$; Coefficients are hierarchical linear regression estimates with robust standard errors.

The results from Table $1 \mathrm{~A}$ indicate that the effect of secondary education on being tolerant toward the rights of homosexuals to run for office is, as we expected, larger for countries with higher national wealth. More technically, the average amount of change in tolerance toward the rights of homosexuals associated with completing secondary school, as opposed to having completed primary school, is larger in richer countries than in poorer countries. This result is statistically significant in all of our multivariate models, even when we include more predictors in the models and the number of countries is reduced. The estimated impact of the investment in education as a percentage of the country's GDP also 
MITCHELL SELIGSON; DANIEL E. MORENO MORALES; GUILHERME A. RUSSO

supports our proposition that more resources matter. The second and third regressions indicate a positive impact of a higher level of expenditure on tolerance toward homosexuals associated with completing secondary school. According to the third model, an increase of $1 \%$ of GDP invested on education is associated with an increase of .25 in the average effect of education.

Honduras represents an interesting case that highlights the importance of expenditures on education. Despite being in the bottom third of the wealth continuum (GNI/pc of US\$2090), in 2013 Honduras invested 5.9\% of government expenditures on education ( $5^{\text {th }}$ in Latin America and the Caribbean), which leads, according to our results, to an effect of secondary education on tolerance of approximately 0.11 , a result similar to a country with a GNI/pc of $\$ 9,350$ and an expenditure on education of $3.5 \%$.

Our estimates of the influence of resources on the effect of post-secondary education presented in Table 1B, however, do not yield results as consistent. While the coefficients for national wealth are positive and large across models, particularly in the third model with Stock of Democracy included, they do not reach conventional levels of statistical significance. Additionally, we do not find a strong association between levels of expenditure on education and a larger change in tolerance toward the political rights of homosexuals as being associated with completing higher education. This result does not mean that post-secondary education is not associated with more tolerance toward homosexuals. As shown in Figure 1, those who complete post-secondary education tend to have higher levels of tolerance than those who complete secondary. But the statistical tests indicate that while the coefficients for GNI/pc are positive and large, at least comparing across Latin America and the Caribbean, we cannot say the level of change associated with earning a higher degree seems to differ according to a country's amount of resources and expenditure on education. We believe this apparently anomalous finding may be attributed to the fact that unlike grade school and high school, higher education in most countries in this region is often dominated by private institutions, which means they should not be as affected by government expenditures compared to public institutions.

The region-level analysis does not yield robust results that point toward any specific relationships between characteristics of subregions and the impact of education. Yet, we recognize this result does not necessarily mean there is not an association between subnational characteristics and educational quality. Most of the countries' sample stratification is designed to capture regional cultural differences, but do not always sort out levels of regional wealth, and more importantly, subnational divisions across school districts.

The models also do not indicate significant differences across the other national-level predictors. However, it is important to note the two-step approach can be relatively inefficient, and the number of observations at the country-level in this analysis is limited, which means the statistical tests of our analysis are conservative (i.e., more likely to yield false negatives). For this reason, we believe the strength of the relationship between resources and the impact of education at the secondary level deserves even more attention. 
The regression table tells us about the direction and statistical significance of the relationship between variables but does not reveal how substantial these changes are. In Figure 2, we graph the impact of education for varying levels of national wealth and percent of government expenditure using the third model for each dependent variable, while holding constant all the other predictors at their means.

Figure 2

Effect of education on tolerance by levels of GNI/pc and expenditures on education

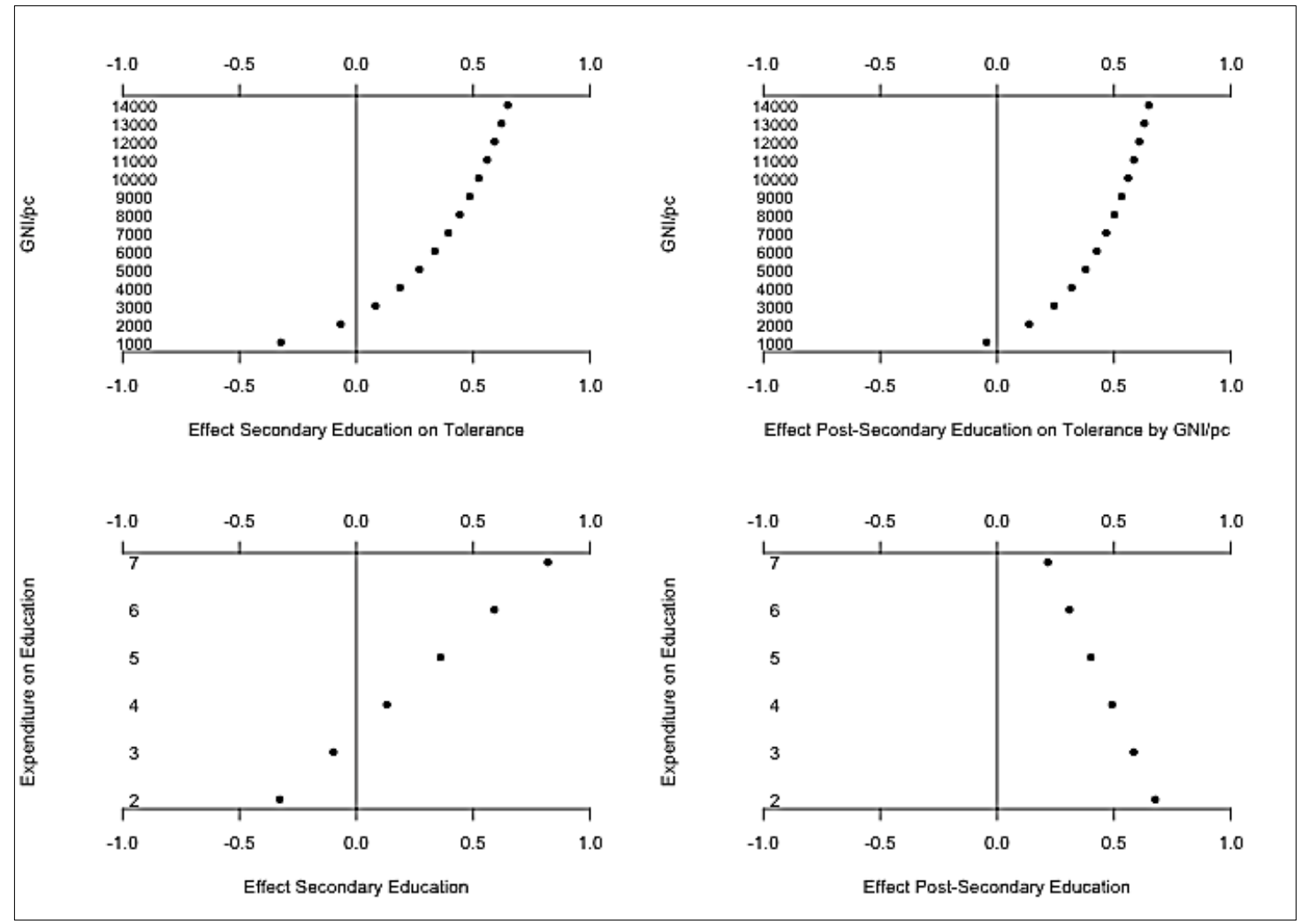

Source: Created by the authors using data from the AmericasBarometer 2014 and the World Bank Databank.

Figure 2 indicates that wealthier countries tend to get a more sizable return in the level of tolerance toward homosexuals from their citizens completing both secondary and post-secondary education. For the level of expenditure, however, this positive effect only holds for secondary education. Another way to assess the importance of these variables is to see how they affect real cases. Figure 3 presents the predicted average scores of tolerance toward the rights of homosexuals to marry by levels of education for three South American 
countries with distinct levels of national wealth: Paraguay, Colombia, and Argentina ${ }^{30}$. According to our hypothesis and model, the effect of education in Paraguay (a poor country) should be close to none, while it should be increasingly positive in Colombia (a middle-income country) and Argentina (one of the richest countries in Latin America).

Figure 3

Predicted average scores of tolerance for varying levels of education in Paraguay, Colombia, and Argentina

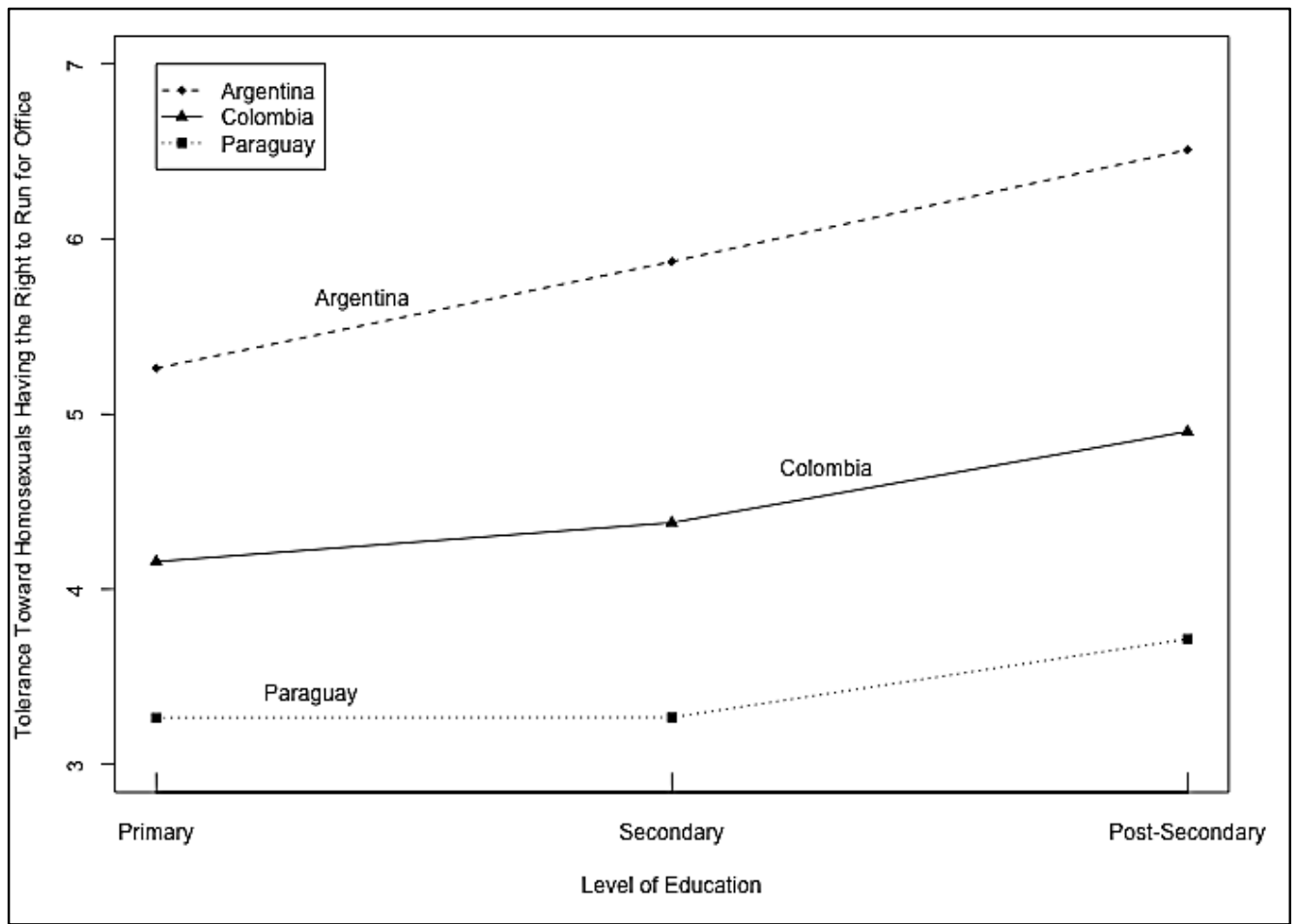

Source: Created by the authors using data from the AmericasBarometer 2014.

Figure 3 shows that while in Paraguay the difference between comparable individuals who completed secondary and primary school is minimal, the change in tolerance toward the political rights of homosexuals associated with finishing secondary school is positive in Colombia and even stronger in Argentina. On the other hand, while the size of the change in tolerance associated with completing post-secondary school is slightly larger for Argentina, the predicted effect is always positive and not distinguishable across the three countries.

30 To produce these graphs, we keep the stratum-level variables fixed across countries, and generate the predicted scores by using the average level of tolerance at the primary level and the predicted effect of completing secondary and post-secondary education according to the country-level variables of each country. 


\section{Conclusion}

Political tolerance has long been seen as an important attitudinal dimension in democracy, and extensive research has documented the importance of education in explaining levels of political tolerance among individual members of a given society. We sought to go beyond the prior research that has looked at the effect of education on tolerance, and previous research that has looked at the role of context on tolerance, by uniquely studying how the effect of education on tolerance toward the rights of homosexuals varies across countries and subnational regions. We ask the following question: does increasing levels of education have a different impact on raising tolerance across national settings? Our results suggest that it does. Completing secondary education is associated with a larger return on increasing tolerance toward homosexuals in wealthier countries compared to poorer countries in the Americas. Our tests also indicate a positive relationship between national wealth and the impact of completing post-secondary education, but this result should not be taken with the same level of confidence as it does reach conventional levels of statistical significance. Our empirical tests also do not allow us to specify the mechanisms behind these relationships. Furthermore, our analytical approach does not account for potential differences in the educational system across generational cohorts, which may serve as an interesting opportunity for future studies. Still, we believe our finding makes an important contribution to our understanding of the impact of education on political tolerance.

For those who seek a more tolerant world, the results presented here suggest that creating that world in poorer countries will be more difficult than in richer countries. According to our results, national wealth seems to have a catalytic effect of education on tolerance. More precisely, we find that in poor countries where education is typically more limited than in richer countries, the impact of completing secondary and post-secondary education is attenuated. We therefore see a low-education/poverty trap that is likely to have adverse consequences for developing a tolerant political culture. Poor countries educate their citizens less, and even when they succeed in raising educational levels, as many countries have done, the impact of education on producing tolerant citizens is constrained. This finding will come as a disappointment to those who believe that education alone is, universally, the solution to the problem of intolerant populations. Yet, our results also point to a way out of this dilemma that could guide policies aimed at promoting tolerant citizens and, by extension, a more democratic society. Our findings highlight the impact of expenditures on education can be an important moderator of the effect of secondary education on tolerance; we have found that investing a higher proportion of the national budget on education can help overcome deficits in national wealth. This suggests that if a country dedicates efforts to improving its education, it may also achieve a larger impact of that education on tolerance. Furthermore, providing accessible post-secondary education, which seems to produce a positive effect on tolerance across countries, to larger shares of the population should also increase national levels of tolerance. 
We therefore have some advice to policy makers living in poor countries interested in creating tolerant societies: get rich, and if you can't get rich, spend more on education. Unfortunately, fiscal realities can get in the way of such policies. Brazil, for example-a country that, according to our model, enjoyed a large positive return on tolerance among those who complete secondary education-has recently imposed a strict austerity program that is estimated to reduce educational expenditures per child by nearly one-third (Watts, 2016). Under those circumstances, the future gains in tolerance from education may be far less robust than in the past.

\section{Bibliographical references}

ADAMCZYK, A.; PITT, C. "Shaping attitudes about homosexuality: the role of religion and cultural context". Social Science Research, vol. 38, no 2, p. 338-351, 2009.

ANDERSEN, R.; Fetner, T. "Economic inequality and intolerance: attitudes toward homosexuality in 35 democracies". American Journal of Political Science, vol. 52, no 4, p. 942-958, 2008.

BEHREND, J. "The uneveness of democracy at the subnational level: provincial closed games in Argentina". Latin American Research Review, vol. 46, nº 1, p. 150-176, Jan. 2011.

BIRDSALL, N.; RoSS, D.; SABOT, R. "Inequality and growth reconsidered: lessons from east Asia". The World Bank Economic Review, vol. 9, no 3, p. 477-508, 1995.

BoBo, L.; LICARI, F. "Education and political tolerance: testing the effects of cognitive sophistication and target group affect". Public Opinion Quarterly, vol. 53, no 3, p. 285, 1989.

Boix, C.; Stokes, S. C. "Endogenous democratization". World Politics, vol. 55, no 4, p. 517-549, Jul. 2003.

BRAUn, M.; BeHR, B.; KACZMIREK, L. "Assessing cross-national equivalence of measures of xenophobia: evidence from probing web surveys". International Journal of Public Opinion Research, vol. 25, no 3, p. 383-395, 2013.

CASPI, D.; Seligson, M. A. "Toward an empirical theory of tolerance: radical groups in Israel and Costa Rica". Comparative Political Studies, vol. 15, p. 385-404, 1983.

Cheibub, J. A.; Gandhi, J.; VReeland, J. R. "Democracy and dictatorship revisited". Public Choice, vol. 143, no $1-2$, p. 57-101, 2010.

CNudde, C. F.; Neubauer, D. E. New trends in democratic theory. In: Cnudde, C. F.; Neubauer, D. E. (eds.). Empirical democratic theory. Chicago: Markham, 1969.

DAHL, R. A. Polyarchy: participation and opposition. New Haven, CT: Yale University Press, 1971.

DION, M. L.; DÍEZ, J. "Democratic values, religiosity, and support for same-sex marriage in Latin America". Latin American Politics and Society, vol. 59, no 4, p. 75-98, 2017.

Duch, R. M.; Stevenson, R. "Context and the economic vote: a multilevel analysis". Political Analysis, vol. 13, no 4 , p. 387-409, 2005.

DYNES, W. "Education and tolerance: an analysis of intervening factors". Social Forces, vol. 46, no 1, p. 22-34, Sep. 1967. 
FALLETI, T. Decentralization and subnational politics in Latin America. New York: Cambridge University Press, 2010.

FRANZESE, C. H. "Empirical strategies for various manifestations of multilevel data". Political Analysis, vol. 13, no 4, p. 430-446, 2005.

FRANZESE, R. J. J. Context matters: the challenge of multicausality, context-conditionality and endogeneity for empirical evaluation of positive theory in comparative politics. In: BOIX, C.; STOKES, S. C. (eds.). The Oxford handbook of comparative politics. New York: Oxford University Press, 2007.

Gelman, A. "Two-stage regression and multilevel modeling: a commentary". Political Analysis, vol. 13, no 4, p. 459-461, Aug. 2005.

GIBSON, E. L. "Politics of the periphery: an introduction to subnational authoritarianism and democratization in Latin America". Journal of Politics in Latin America, vol. 2, p. 3-12, 2010.

GIBSON, J. L. "Political intolerance and political repression during the McCarthy red scare". American Political Science Review, vol. 82, p. 511-529, 1988.

. "Alternative measures of political tolerance: must tolerance be 'least-liked?'". American Journal of Political Science, vol. 36, p. 560-577, May 1992.

"Enigmas of intolerance: fifty years after stouffer's communism, conformity, and civil liberties". Perspectives on Politics, vol. 4, nº 1, p. 21-34, Mar. 2006.

"Intolerance and political repression in the United States: a half-century after McCarthyism". American Journal of Political Science, vol. 52, no 1, p. 96-108, Jan. 2008.

"Measuring political tolerance and general support for pro-civil liberties policies: notes, evidence and cautions". Public Opinion Quarterly, vol. 77, no 1, p. 45-68, 2013.

GIRAUDY, A. "Subnational democracy: lessons from Latin America". APSA Comparative Democratization Newsletter, vol. 10, nº 1, p. 1-8, 2012.

HEINZE, J.; HORN, S. S. "Intergroup contact and beliefs about homosexuality in adolescence". Journal of Youth Adolescence, vol. 38, p. 937-951, 2009.

HISKEY, J. "The political economy of subnational economic recovery in Mexico". Latin American Research Review, vol. 40, no 1, p. 30-49, Feb. 2005.

Hooghe, M., et al. "Anti-gay sentiment among adolescents in Belgium and Canada: a comparative investigation into the role of gender and religion". Journal of Homosexuality, vol. 57, no 3, p. 384-400, 2010.

Huber, E.; Mustillo, T.; Stephens, J. D. "The politics of social spending in Latin America". Journal of Politics, vol. 70, no 2, p. 420-436, 2008.

INGLEHART, R. The silent revolution: changing values and political styles among western publics. Princeton, NJ: Princeton University Press, 1977.

. "The renaissance of political culture". American Political Science Review, vol. 82, no 4, p. 1.203-1.230, Dec. 1988.

Culture shift in advanced industrial society. Princeton: Princeton University Press, 1990.

Modernization and postmodernization: cultural, economic and political change in 43 societies. Princeton, NJ: Princeton University Press, 1997. 
MITCHELL SELIGSON; DANIEL E. MORENO MORALES; GUILHERME A. RUSSO

IngLehART, R. Culture and democracy. In: HARRISON, L. E.; HUNTINGTON, S. P. (eds.). Culture matters: how values shape human progress. New York: Basic Books, p. 80-97, 2000.

INGLEHART, R.; NORRIS, P. Rising tide: gender equality and cultural change around the world. Cambridge, UK; New York: Cambridge University Press, 2003.

InglehaRT, R.; Welzel, C. Modernization, cultural change, and democracy. New York: Cambridge University Press, 2005.

JACKMAN, R. W. "Political elites, mass politics, and support for democratic principles". Journal of Politics, vol. 34, no 3, p. 752-764, 1972.

JACKSON, C. K.; JOHnSON, R. C.; PeRsico, C. "Boosting educational attainment and adult earnings". Education Next, vol. 15, no 4, p. 69-76, Fall 2015.

"The effects of school spending on educational and economic outcomes: evidence from school finance reforms". Quarterly Journal of Economics, vol. 131, no 1, p. 157-218, Feb. 2016.

JUSKO, K. L.; SHIVELY, W. P. "Applying a two-step strategy to the analysis of cross-national public opinion data". Political Analysis, vol. 13, no 4, p. 327-344, 2005.

KIRCHNer, A.; FReITAG, M.; RAPP, C. "Crafting tolerance: the role of political institutions in comparative perspective". European Poltical Science Review, vol. 3, no 2, p. 201-227, 2011.

LAfortune, J.; Rothstein, J.; SCHANZENBACH, D. W. School finance reform and the distribution of student achievement. National Bureau of Economic Research. Cambridge, Feb. 2016.

LIPSET, S. M. "Some social requisites of democracy: economic development and political legitimacy". American Political Science Review, vol. 53, p. 65-105, Mar. 1959.

Political man: the social bases of politics. Expanded edition, 1981. Baltimore, MD: Johns Hopkins University Press, 1961.

MCGUIRE, J. W. "Development policy and its determinants in East Asia and Latin America". International Journal of Public Policy, vol. 14, no 2, p. 205-242, 1994.

MONDAK, J. J.; SANDERS, M. S. "Tolerance and intolerance, 1976-1998". American Journal of Political Science, vol. 47, no 3, p. 492-502, Jul. 2003.

Moreno, D.; Seligson, M. Educación y tolerancia política en Bolivia. In: Seligson, M. A.; Moreno, D. (eds.). La cultura política de los Bolivianos: aproximaciones cuantitativas. Cochabamba: Ciudadanía Lapop-Usaid, 2006.

Nie, N. H.; JUnN, J.; Stehlik-BARRY, K. Education and democratic citizenship in America. Chicago: University of Chicago Press, 1996.

NunN, C. A.; CRockett, H. J.; Williams, J. A. Tolerance for nonconformity: a national survey of changing commitment to civil liberties. San Francisco: Jossey-Bass, 1978.

ORTMANNS, V.; SCHNeIdeR, S. L. "Harmonization still failing? Inconsistency of education variables in cross-national public opinion surveys". International Journal of Public Opinion Research, vol. 28, no 4, p. 562-82, Dec. 2016.

Peffley, M.; Hutchison, M. L.; ShamiR, M. "The impact of persistent terrorism on political tolerance: Israel, 1980 to 2011". American Political Science Review, vol. 109, no 4, p. 817-832, Nov. 2015. 
Peffley, M.; Rohrschneider, R. "Democratization and political tolerance in seventeen countries: a multi-level model of democratic learning". Political Research Quarterly, vol. 56, n 3, p. 243-257, Sep. 2003.

Prothro, J. W.; GRIGG, C. M. "Fundamental principles of democracy: bases of agreement and disagreement". Journal of Politics, vol. 22, n 2, p. 276-294, 1960.

PRZEWORSKI, A., et al. Democracy and development: political institutions and well-being in the world, 1950-1990. Cambridge: Cambridge University Press, 2000.

Puryear, J.; ORtegA, T. "How can education help Latin America develop?". Global Journal of Emerging Market Economies, vol. 3, no 1, p. 111-134, 2011.

RAPP, C.; FREITAG, M. "Teaching tolerance? Associational diversity and tolerance". Political Studies, vol. 63, no 5, p. 1.031-1.051, Dec. 2015.

SELIGSON, M. A. "The renaissance of political culture or the renaissance of ecological fallacy". Comparative Politics, vol. 34, p. 273-292, Apr. 2002.

SELIGSON, M. A.; CASPI, D. "Challenging the pluralistic intolerance thesis: a reply". Comparative Political Studies, vol. 17, p. 345-350, Oct. 1984.

Steenbergen, M. R.; Jones, B. S. "Modeling multilevel data structures". American Journal of Political Science, vol. 46, no 1, p. 218-237, 2002.

Stojnic, L.; Alfaro, A. R. "Experiencia educativa y tolerancia política: el caso de una muestra de estudiantes universitarios peruanos". Revista Internacional de Educación para la Justicia Social, vol. 5, no $1,2016$.

Stouffer, S. C. Communism, conformity and civil liberties. New York: Doubleday, 1955.

Sullivan, J. L.; Pierson, J. E.; MARCus, G. E. "An alternative conceptualization of political tolerance: illusory increases 1950s-1970s". American Political Science Review, no 73, p. 781-794, 1979.

Political tolerance and American democracy. Chicago: University of Chicago Press, 1982.

Van Den Akker, H.; Ploeg, R. V. D.; Scheepers, P. "Disapproval of homosexuality: comparative research on individual and national determinants of disapproval of homosexuality in 20 European countries". International Journal of Public Opinion Research, vol. 25, no 1, p. 64-86, 2013.

VATter, A.; StAdelmanN-StefFen, I.; DANACI, D. "Who supports minority rights in popular votes? Empirical evidence from Switzerland". Electoral Studies, vol. 36, p. 1-14, 2014.

WAGNER, U.; ZICK, A. "The relation of formal education to ethnic prejudice: its reliability, validity and explanation". European Journal of Social Psychology, vol. 25, p. 41-56, 1995.

WATTS, J. Brazil's austerity package decried by UN as attack on poor people. London: The Guardian, 2016. Available at: <https://www.theguardian.com/world/2016/dec/09/brazil-austerity-cuts-unofficial>. Accessed on: January 15, 2017.

WELDON, S. A. "The institutional context of tolerance for ethnic minorities: a comparative, multilevel analysis of Western Europe". American Journal of Political Science, vol. 50, no 2, p. 331-349, 2006.

Welzel, C.; Inglehart, R. Mass beliefs in comparative politics. In: BoiX, C.; Stokes, S. C. (ed.). The Oxford handbook of comparative politics. New York: Oxford University Press, 2007. 


\section{Resumo}

Educação, riqueza das nações e tolerância política aos homossexuais: uma análise multinível de 26 países das Américas

Enquanto o efeito positivo da educação na tolerância política às minorias é bem conhecido, entendemos muito menos sobre o impacto da educação sobre a tolerância em diferentes contextos. Utilizando técnicas de análise multinível, encontramos um efeito interativo que indica que a educação em nível individual tem um efeito maior sobre a tolerância política em relação àqueles que se identificam como homossexuais nos países mais ricos. Os resultados sugerem que a conclusão de níveis adicionais de escolaridade pode ser insuficiente para promover atitudes tolerantes em relação a essa minoria, e que mais investimentos em educação levam a impactos mais fortes. Corroboramos esse resultado ao mostrar que, onde os gastos com educação são maiores, o impacto médio do ensino médio também é maior. O artigo usa dados de pesquisas de tipo survey em 26 países conduzidas pelo Barômetro das Américas de 2014 e indicadores do DataBank do Banco Mundial e Freedom House.

Palavras-chave: tolerância política; opinião pública; América Latina; homossexuais

\section{Resumen}

Educación, la riqueza de las naciones y tolerancia política hacia los homosexuales: un análisis multinivel de 26 países de las Américas

Mientras el efecto positivo de la educación sobre la tolerancia política con las minorías es bien conocido, entendemos mucho menos sobre el impacto de la educación en la tolerancia en diferentes contextos. Al utilizar técnicas de análisis multinivel, encontramos un efecto interactivo que indica que la educación a nivel individual tiene un mayor impacto sobre la tolerancia política hacia aquellos que se identifican como homosexuales en países más ricos. Los resultados sugieren que completar niveles adicionales de educación puede ser insuficiente para promover actitudes tolerantes hacia esta minoría, y que más inversión en educación lleva a mejores retornos. Corroboramos este resultado al mostrar que, donde los gastos educativos son mayores, el impacto promedio de la educación secundaria también es más grande. El estudio utiliza datos de encuestas conducidas en 26 países por el Barómetro de las Américas 2014 e indicadores del DataBank del Banco Mundial y Freedom House.

Palabras clave: tolerancia política; opinión pública; América Latina; homosexuales

\section{Résumé}

Éducation, la richesse des nations et tolérance politique à l'égard des homosexuels: une analyse multiniveau de 26 pays des Amériques

Si l'effet positif de l'éducation sur la tolérance politique à l'égard des minorités est bien connu, nous en savons beaucoup moins sur l'impact de l'éducation sur la tolérance dans différents contextes. En utilisant des techniques d'analyse à plusieurs niveaux, nous trouvons un effet interactif indiquant que l'éducation au niveau individuel a un effet plus important sur la tolérance envers ceux qui s'identifient comme homosexuels dans les pays plus riches. Les résultats suggèrent que le fait d'atteindre un meilleur niveau d'éducation peut être insuffisant pour promouvoir des attitudes plus tolérantes à l'égard de cette minorité, et qu'un investissement accru dans l'éducation conduit à de meilleurs rendements. Nous soutenons ce résultat en montrant que lorsque les dépenses d'éducation sont plus élevées, l'impact moyen de l'éducation secondaire est plus grand. L'étude utilise des données de l'enquête Baromètre des Amériques dans 26 pays et des indicateurs du DataBank de la Banque Mondiale et de Freedom House.

Mots-clés: tolérance politique; opinion publique; Amérique Latine; homosexuels

Artigo submetido à publicação em 31 de agosto de 2018. Versão final aprovada em 18 de junho de 2019.

Opinião Pública adota a licença Creative Commons CC-BY. 